\title{
SIX NEW OR LITTLE KNOWN LARVAE OF PTEROPHORIDAE.
}

\author{
BY HARRISON G. DYAR, WASHINGTON, D. C.
}

Trichoptilus lobidactylus Fitch. - Head faintly brownish, retracted at the apex under joint 2 ; width $.7 \mathrm{~mm}$. Body shining green, semi-transparent; no marks; tracheal line faintly showing by transparency, dorsal vessel darker. Warts rather few haired, and ii united into a single wart, iii small, a single hair above and behind spiracle (iiia) iv and $v$ united, vi and vii small; a few short secondary hairs subventrally; all the hairs glandular and gummy, swollen at the tips even without a lens and often with drops along the shaft. The hairs are sordid white, sparse, and rise I $\mathrm{mm}$. above the dorsum. A row of minute, impressed, black dorsal dots on joints 5 to II. At the bases of the several hairs are brown rings, causing the warts to appear slightly discolored. In $\delta$ larvae the sex-glands appear in joint 9, yellowish, not pronounced.

Pupa. Attached by the cremaster; without winged elevations; green, vinous patch on segments 4-5 of abdomen. Head roughened with coarse tubercles, vinous brown; thorax obliquely truncate anteriorly, rounded; hairs shorter and fewer than in the larva, scarcely glandular. Length $8 \mathrm{~mm}$.

On smooth leaved golden-rod (Solidago), Van Cortlandt Park, New York City, May.

Oxyptilus tenuidactylus Fitch. - Head green, $.7 \mathrm{~mm}$. wide. Body pale green, with a faint sub-dorsal white band. Warts $i$ and ii united, bearing about ten setae with simple ends; iii with six setae; a small wart behind it with two setae (iiia); iv $+v$ with two large setae and several small ones; a single seta behind this (iii b); vi with a distinct tubercle, but somewhat confused among the secondary hairs; vii of three large setae with several shorter ones; secondary hairs scat- tered over the body, and these as well as some shorter ones from the warts, have swollen or cleft tips.

Pupa. Slender, tapering behind, fastened by the cremaster. A row of sub-dorsal tubercles bearing four spines in a fan-like arrangement, continued as a carinated ridge on the thorax. Thorax widened, the cases produced into a point along the abdomen. Two slight points above the eyes. Whitish green, cases more greenish. There are several spines on the thorax, and some fine, soft hairs on abdomen laterally. Another pupa was light purplish brown.

On the buds of blackberry (Rubus), Keene Valley, N. Y., June. Found with Butalis basilaris Zell., but more closely resembles the blackberry buds than this Tineid does.

Pterophorus rhynchosiae n. sp. - Expanse I $8 \mathrm{~mm}$. Head and thorax yellowish gray; abdomen neatly lined with brown; a mediodorsal and six lines on each side; above, the first and third segments are tufted with white posteriorly; legs pale yellow, white towards the tips, narrowly lined with brown longitudinally. Fore-wings yellow-gray ; a small double black dot at base of fissure, and one half way between this and base; a minute dot towards apex of first lobe. Fringe pale, the outer third on first lobe black; terminal part of fringe of second lobe blackish, basal part pale, cut by five black wisps; the fifth at apex. Hind wings blackish, a black dot at apex of each lobe; base of fringe of third feather whitish, contrasting.

Larva. Downy, pale green, with short white hairs. Pale green, the body tapering a little posteriorly; no marks except a very faint, whitish subdorsal line along warts $i$ and $\mathrm{ii}$; warts small, $\mathrm{i}$ and $\mathrm{ii}$ separate, but somewhat approximate; a small wart (iiia) 
below and behind iii ; iv $+\mathrm{v}$ distinct with a small wart (iiib) behind; skin densely covered with very short, white, club-tipped secondary hairs. Feet short.

On the young leaves of a trailing plant (Rhynchosia) at Miami, Fla. December.

Pterophorus elliotii Fernald. - The moths both in color and the structure of the genitalia correspond with Prof. Fernald's species rather than with $P$. homodactylus Wlk; yet I doubt the specific distinctness of these forms. It is easy to understand the occurrence of two "plume" larvae on Eupatorium, as they have different habits; but there scarcely seems room for a third one. Kellicott's description of homodactylus fits elliotii.

Larva. Head pale, eye black; width I.9 $\mathrm{mm}$. Body green, subdorsal and stigmatal bands slender, whitish shades, the former along warts $i$ and $i i$; a waved lateralline, bent down behind tubercle iii and a narrow dorsal line. Hair long, white, rather abundant. No secondary hairs. Tubercles $i$ and $i$ are distinct, but contiguous, in line; a single hair (iiia) behind and below iii ; a small wart of two hairs (iii b) behind iv $+v$; vi and vii several haired. Skin with sparse, minute, clear granules. In the $\delta$ the dorsum of joint 9 is all diffusely yellowish.

Pupa. Fastened by cremaster, much resembling the larva in appearance. Green with the same marks as the larva; the $\delta$ sex-glands visible. The cases reach to the middle of fourth abdominal segment, the leg cases to the seventh. The hairs are roughly arranged as in the larva, but the warts are diffuse, scattered, and there is a median dorsal hair; the hairs are also shorter.

Exposed feeders on the young leaves of Eupatorium at Van Cortlandt Park, New York City. May.

Pterophorus eupatorii Fernald. - Closely allied to the preceding, the warts arranged the same. Color the same, till the last stage when the dorsum becomes all suffused with reddish. The hairs are shorter than in $P$. elliotii and the dorsal ones are blackish in- stead of white. There is a pale line along warts iv $+v$. Hairs pointed, slightly barbuled.

The larvae live on the under sides of the leaves which they bend together with webby silk.

On Epilobium, Van Cortlandt Park, New York City.

Pterophorus cretidactylus Fitch.-Head rounded, higher than wide, partly retracted; green, ocelli black. Body a little thickest in the middle, uniform green with a whitish dorsal line. Warts round, concolorous, $i$ and ii near each other but separate, a small wart (iii a) below and behind iii; another (iii b) behind iv $+v$, vi and vii not large. Feet normal, the abdominal ones slender, wider at the claspers.

Pupa suspended by the cremaster, slender; cases projecting over the abdomen half way to the tip. Uniformly green, covered with tufts of sparse radiating hairs, arranged roughly as in the larvae. Length II $\mathrm{mm}$., width $2.5 \mathrm{~mm}$. On aster*, Yosemite, Cal. June.

\section{Synopsis of larvae here described.}

Warts $i$ and ii united; secondary hairs present.

Hairs sticky glandular; on Solidago

Hairs not sticky; on Rubus

$$
\text { T. lobidactylus }
$$

Warts $i$ and ii separate.

O. tenuidactylus

Secondary hairs present; on Rhynchosia P. rhynchosiae

No secondary hairs.

A waved subdorsal line below wart ii; on Eupatorium.

Hair long $(3-3.5 \mathrm{~mm}$.) exposed feeding $P$. elliotii

Hair short (1.6-1.8 mm.) concealed feeding P. eupatoriz No waved subdorsal line; on aster

P. cretidactylus

* This plant was not determined with certainty. 

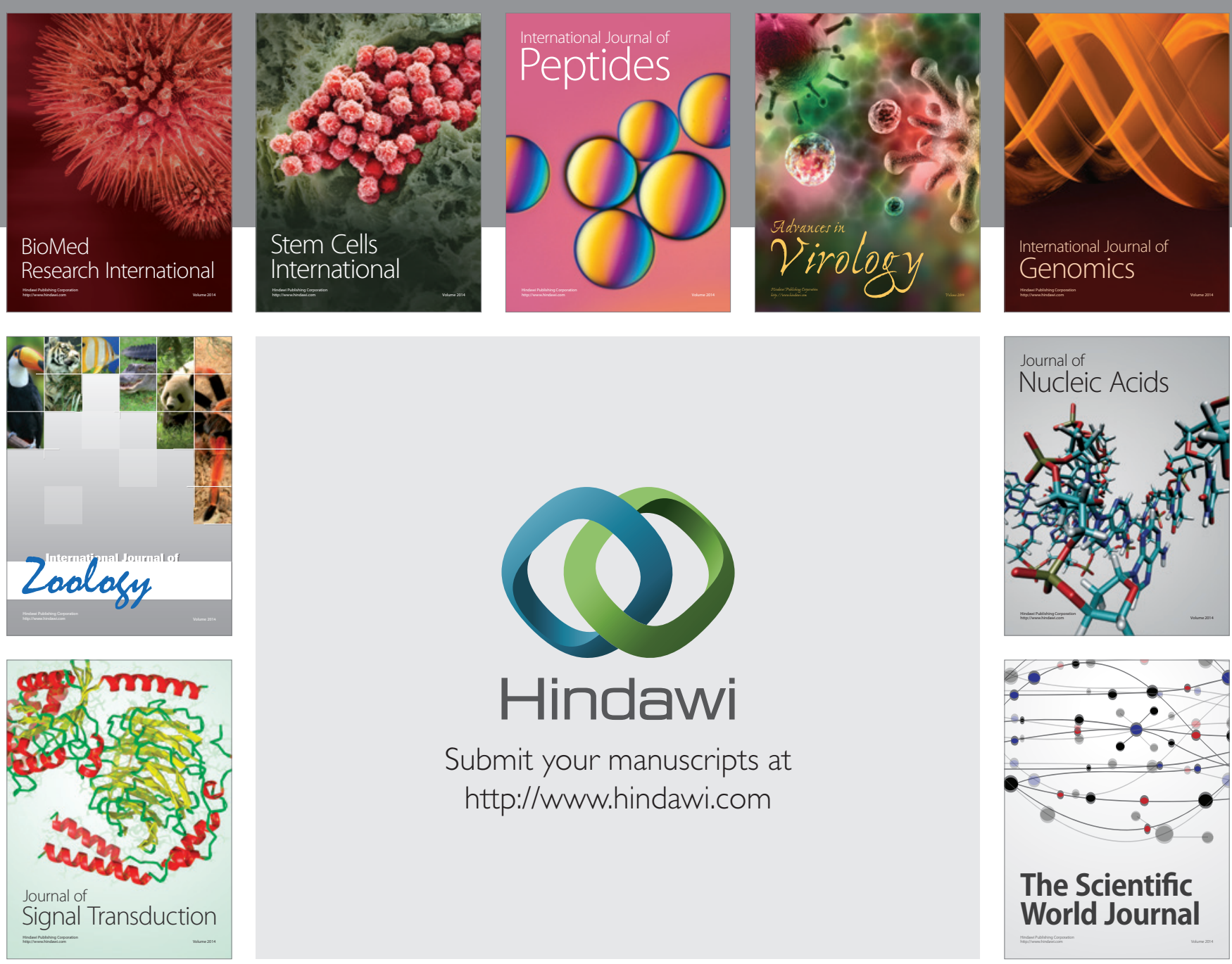

Submit your manuscripts at

http://www.hindawi.com
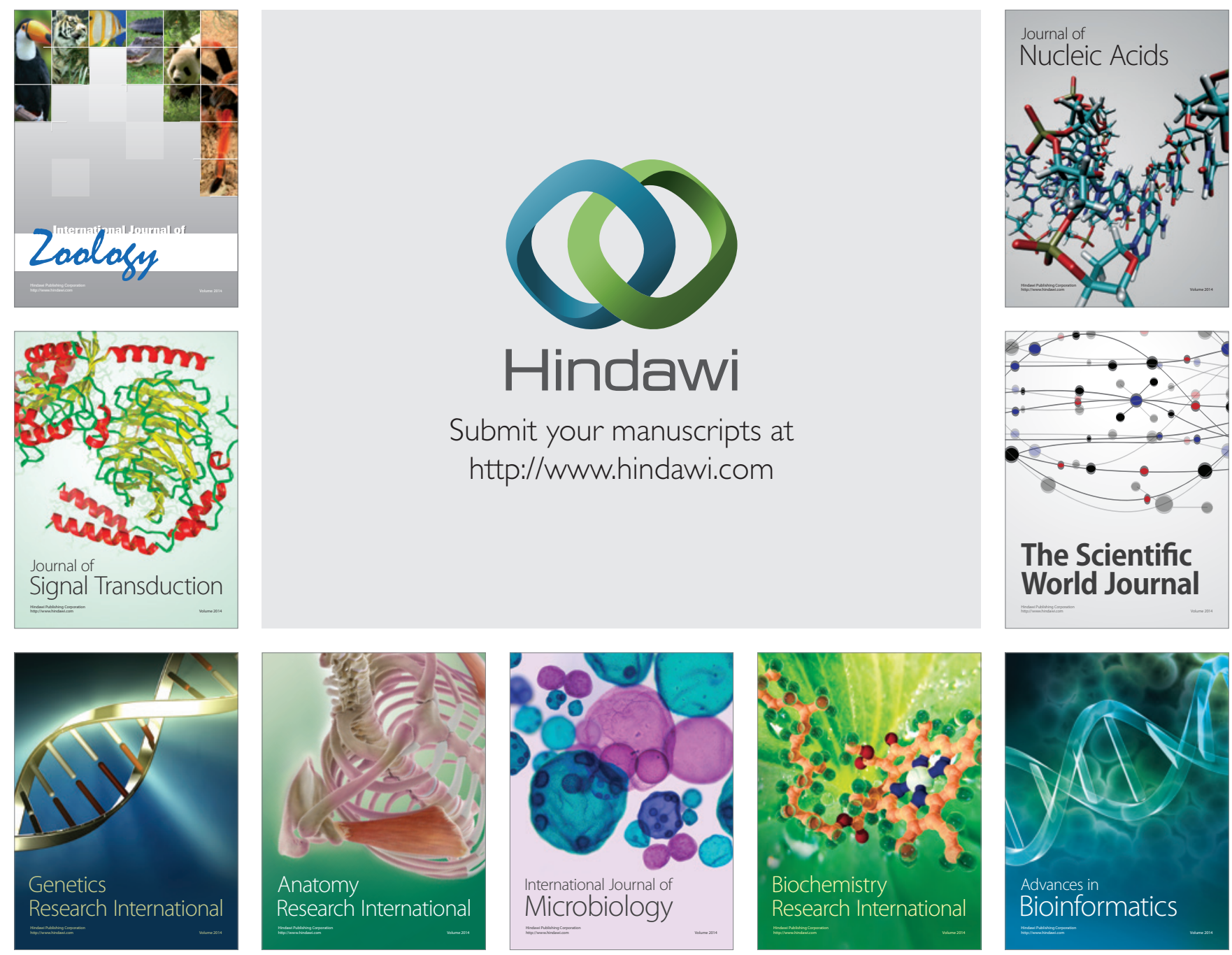

The Scientific World Journal
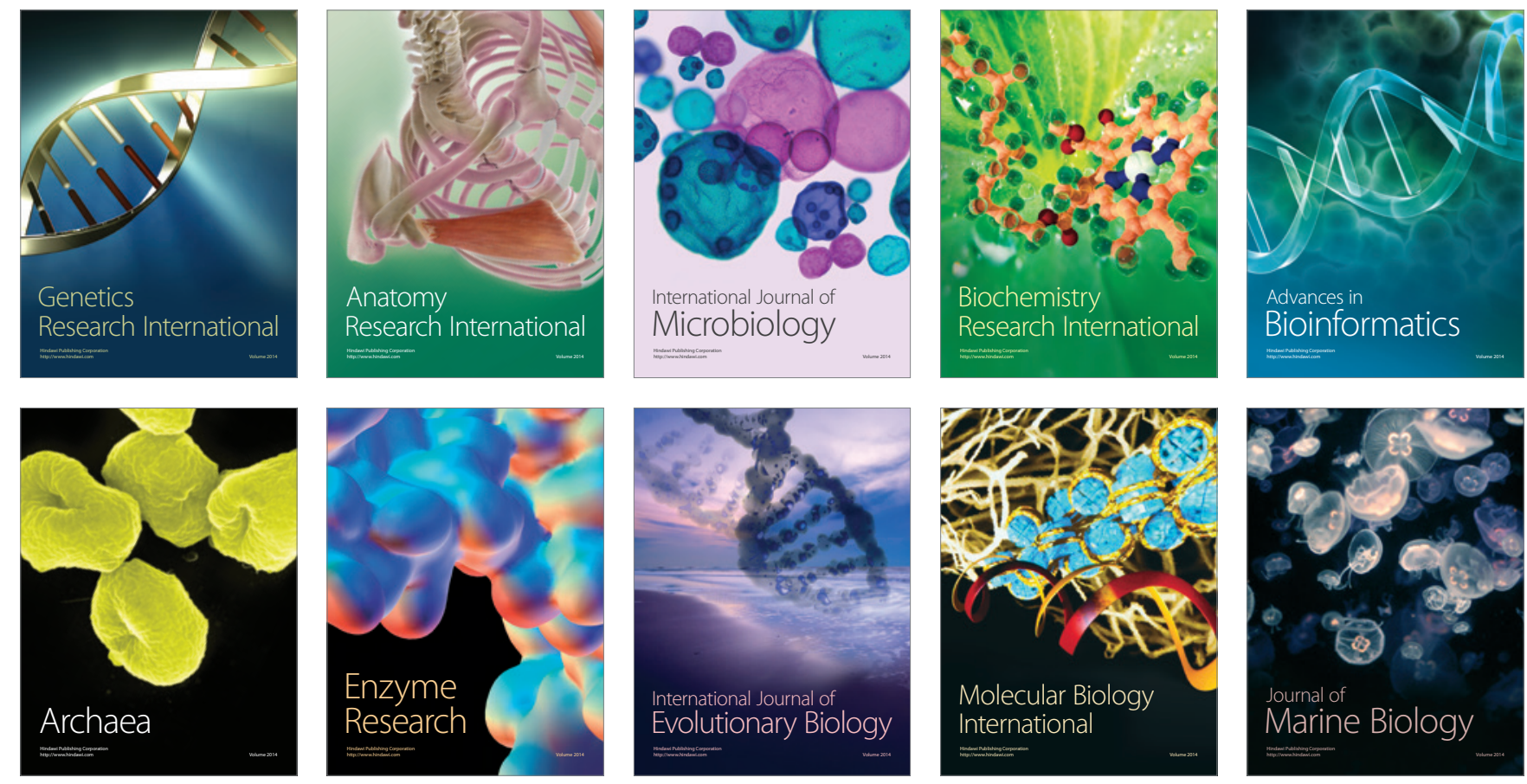